\title{
Devolution In Regional Devices Units In The Sub- District: A Review Of Paradigm Construction In Improving Public Services In Sidoarjo Regency
}

\author{
Lukman Arif ${ }^{1}$, Diana Hertati ${ }^{2}$ \\ \{ lukman_arif.adneg@upnjatim.ac.id ${ }^{1}$, dianahertati.dh@gmail.com² \} \\ Universitas Pembangunan Nasional Veteran Jawa Timur ${ }^{1}$ \\ Universitas Pembangunan Nasional Veteran Jawa Timur ${ }^{2}$
}

\begin{abstract}
Devolution is the derivation of the decentralization concept, in terms of is meant as the transfer of authority from the central government to regions within its jurisdiction. This study's devolution concept explains and analyzes the phenomena of decentralization of part of the Regent authority to regional officials in the-sub-district. Part of the Regent government's decentralization has not improved public service quality in the sub-district area. Community civil rights, such as ownership of various that are very basic for assets and economic activities of the community, cannot be fulfilled optimally. This study offers conceptual ideas that depart from the results of research that are expected to fulfill society's civil rights as citizens. This research method uses a descriptive qualitative approach. Data were collected using the method form of observation, interviews, and documentation. The data that has been collected is simplified through the condensation stage. Furthermore, the information is presented under the focus of the study for later conclusions to be drawn. This study's results are expected that through the decentralization of part of the Regent authority in the form of devolution, it will give the district head broader in making decisions. Devolution can give the Head of District more accountability for service delivery. Besides, through devolution, potential sources in the sub-district can provide financial support in improving public service delivery quality in the sub-district.
\end{abstract}

Keywords: Decentralization, Devolution, Public Services, and Service Quality.

\section{Introduction}

In many cases, since rolled out this decentralization policy in Indonesia, the Regional Government (Regency / City) has been flooded with the Central Government's functions. It then becomes the responsibility or right of regional autonomy. Based on Law No. 32 of 2004, it is stated that decentralization is the transfer of government authority by the central government to autonomous regions. To regulate and manage government affairs in the system of the Unitary State of the Republic of Indonesia.

In the last two decades, decentralization initiatives in developing countries have emerged as an essential regional development policy instrument. Government through decentralization of decision-making achieves multiple objectives: among them community participation, social capital development, resource management, and sustainable development of community resources and service provision at the local level [3], [4], [6], [9], [10]. 
Decentralization is the principle of governance as opposed to centralization. Decentralization has resulted in autonomous regional government. In practice, this decentralization transfers part of the central authority to provincial governments [5]. This transfer of some of the central powers to local governments is an essential difference between decentralization and centralization.

However, this clear difference in concept becomes dim when applied to the real dynamics of government. Some interpret decentralization as political decentralization (devolution) and administrative decentralization (deconcentration). Some think that decentralization is devolution [7].

This difference arises from the meaning of the term decentralization itself. Political experts agree that the adoption of decentralization is so that government policies are on target. They are following the conditions of the region and local communities. This difference is striking when it comes to the best way to manifest this desire.

Many hopes are based on this decentralization policy, from equitable regional distribution, development in more democratic life, encouraging community empowerment, fostering initiative and creativity, and providing better and better quality community services. This picture of the expected government through decentralization policies is also alluded to by [1]. He illustrates that decentralization is sometimes seen as a good thing because policymakers more often define their policy options based on increased efficiency, more significant equity, and higher responsiveness to citizens, [2] describe the perceived benefits of decentralization, including greater access to decision-makers, higher participation levels by various social groups in decision-making, and accountability of decision-makers.

There are several important aspects to highlight concerning this decentralization policy. First of all, apart from devolving administrative and expenditure responsibilities to local governments, it also involves decentralization, at different levels, changes in the administrative level of decision-making, and decision-making authorities (political or bureaucratic), and their nature and number of available fiscal resources. Second, the decentralization process is not uniform across functions, with significant heterogeneity in coverage not only across different regency/city governments but often across multiple services. Of course, this condition can be understood because each region" s potential conditions have other characteristics. What is certain is that with this decentralization, the functions that are the responsibility of the regional government are getting bigger.

Its implementation cannot avoid implementing the increasing number of regional government affairs from gradual decentralization, namely the decentralization of authority from the regent/mayor to the regional apparatus under him. Whether the decentralization of part of the powers to their regional apparatus is administrative decentralization, is it devolution?

\section{Methodology}

The research analysis unit feels small enough to take sub-district institutions small to analyze devolution at the district-wide level. For this reason, researchers measure this decentralization (devolution) directly on the number of services delegated by the Regents to the Head of District. The researcher will take one example of the licensing service as one of the Head of the District. The focus of this research took the setting in Waru and Sedati Districts as sampling. The data collected in this study are primary in interviews and secondary data, which are sourced from documents that explain the phenomenon under review. Data analysis was 
carried out interactively, starting from the stages of data collection, data condensation, data presentation, and concluding [8].

\section{Finding and Discussion}

\subsection{Decentralization in an Empirical Perspective}

In its implementation, decentralization in the Sidoarjo Regency Government runs by the corridors of applicable regulations. As the holder of decentralized power, the Regents in carrying out his duties also delegates part of his authority to the regional apparatus. The Regents decentralization to regional apparatuses that have an exact territory and structure and in the future deserves to be given legal legitimacy in managing the potential and resources that are owned independently and independently is the sub-district.

In Government Regulation Number 19 of 2008 junto Government Regulation Number 17 of 2018 concerning District, the sub-district is the Head of District's work area as a regency/city Regional Apparatus. At the same time, the Head of District is the leader and coordinator of government administration in the sub-district working area. In carrying out its duties, it receives governmental authority from the Regent / Mayor to handle regional autonomy affairs and carry out general government tasks. The statement as contained in the policy shows it is clear that the sub-district is carrying out decentralization tasks to implement its duties. In the Sidoarjo Regency, the delegation of some of the Regent's authority to the Head of District is stated in Regent Regulation Number 4 of 2019. The policy states what government affairs and how much authority is delegated is strictly regulated. Along the way, this policy will change in 2020.

Based on the Sidoarjo Regent Regulation Number 22 of 2020 concerning Amendments to Regent Regulation Number 4 of 2019 concerning the Delegation of Part of the Authority of the Regent to the Head of District, there are two (2) additional functions delegated, namely matters of Housing and Settlement Areas; as well as the social sector. So that overall, the delegation of part of the Regent's authority to the Head of District includes government affairs in the following areas:

a. Community and Village Empowerment;

b. Public Works and Spatial Planning;

c. Administration of Population and Civil Registration;

d. Transportation;

e. Labor;

f. Women's Empowerment and Child Protection;

g. Population Control and Family Planning;

h. Industry;

i. Trading;

j. Peace, Public Order, and Community Protection;

k. Living environment;

1. Housing and Settlement Areas;

m. Social.

Based on the 2020 Regent Regulation, the total number of government affairs delegated by the Sidoarjo Regent to the Head of District is 13 government affairs. These 13 governmental affairs are not easy things in implementation but need adequate resources in terms of quantity and quality to carry out the delegation tasks properly. One part of the delegation of authority is public service matters.

As one of the sub-districts affairs, public services can be divided into two parts: licensing services and non-licensing services. The criteria for licensing services are: 
a. simple process;

b. small-scale licensing objects;

c. does not require complex technical studies, and

d. does not require high technology.

e., done through integrated services.

f. developed as a public service innovation by the provisions of laws and regulations invitation.

Meanwhile, non-licensing services are carried out with the following criteria:

a. relating to the supervision of the object of the permit;

b. small scale activities; and

c. direct service to the community that is routine.

In this article, the researcher will describe the implementation of licensing services in the sub-district. There are types of licensing services provided to the community, including building construction permits (IMB), micro and small business permits (IUMK), incidental billboard permits, and other permits by the assignment given to the sub-district head. The delegation of authority granted by the Regent to the sub-district, for example, the issuance and signing of a Building Construction Permit (IMB) for a one-story and two-story residential house with a maximum building area of $400 \mathrm{~m} 2$, in addition to the initial building construction permit (developer) or a multi-story building.

Implementing licensing services in the sub-districts follows the applicable regulations regulated either through regional regulations or by regent regulations. Licensing services are generally implemented if the community, as service users, wish to receive services. This service assignment will be processed or carried out if an applicant comes to arrange a permit. If there is no applicant, the process of carrying out the service task will not occur. Thus implementing officers are not too busy outside of the administrative work they carry out routinely, except for licensing services that contribute to regional revenue.

For services that contribute to local revenue, such as IMB and Incidental Billboard Permits, service providers have a work agenda prepared to carry out these licensing service tasks even though at an elementary level. Example: For IMB licensing services, work tasks are carried out, for example, conducting socialization, making retribution targets in the current fiscal year, conducting operations to educate people who want to build. At the time the licensing service process runs (IMB), the details of the tasks carried out are under the following technical provisions:

a. The applicant submits a written application to the Head of District under the form of application that has been determined along with the completeness of the requirements; b. Sub-district officer (customer service) checks and examines the application and the completeness of the requirements and gives a receipt when the application file is complete; c. The assigned sub-district officer (Section Head) validates documents, plans and coordinates field reviews and calculates user fees;

d. The sub-district officer who is assigned (Head of Section) signs the Minutes of Field Review (approved or rejected) after receiving technical considerations from the Technical Team;

e. The Head of District signs the Building Construction Permit Decree with a copy of the Head of the One-Stop 
f. Investment and Integrated Services Service and the Head of the Housing, Settlements, Cipa Karya, and Spatial Planning Service;

g. The officer submits the Building Construction Permit Decree to the applicant after the applicant has paid retribution;

$\mathrm{h}$. The officer recapitulates the building construction permit services every month.

This licensing service's task can generate genuine income for the region and provide services as a right that must be given to the community as citizens. If the sub-district tries to identify each neighborhood in the area under its authority, there will be a gap in the number of buildings with IMB and those that do not; the more definitely buildings that do not have a building permit. This researcher's assumption is quite reasonable because people who live in village settlements or are not in a residential area developed by the developer are sure to build without being equipped with an IMB permit as the legal legality of building a building. The number of settlements in this village is far more, of course, compared to the settlements developed by the developer. This condition is quite potential, although data on this matter are not available in the sub-district.

The environmental impact on the condition of the people who built without a permit was certainly felt not only for the community but also for the local government. For the community, because the residential environment is not neatly arranged, the impact is that the community feels uncomfortable. Public space is not available to feel crowded and unhealthy. For local governments, in this unkempt environment, the area seems slum. This condition impacts health and the emergence of community problems that require serious handling by the local government. Besides, a building that does not have an IMB means that it does not pay fees, thus no revenue for the region.

Many reasons underlie people who do not have a building permit for the house they occupy. These reasons include the lack of awareness of the importance of the IMB; feel the cost of processing is expensive, do not have the cost to take care of an IMB. These reasons are entirely plausible; for the wealthy, this awareness is essential for IMB ownership. Meanwhile, for people who cannot afford it, the obligation to take care of this IMB is very burdensome. For people who are vulnerable to economic problems, the local government could provide subsidies or exemption fees to obtain a building permit. During the Covid-19 pandemic, the Sidoarjo Regency Government only provided a 15\% discount for the people who administered the IMB.

The Head of District as the service provider only carries out the tasks as specified in the regulations. There is no authority that the Head of District can exercise outside of the Regent provisions that have delegated the functions to be implemented - identifying buildings that have IMB or not are the main tasks that must be carried out. This means that these tasks are not regulated in the policy. Besides that, there is also no program in the activity plan that will be carried out in the current year to identify. Moreover, doing a mapping plan for giving IMB for poor people, no planning for that. This is not in his authority at all, unless there is a policy regulating this matter. The sub-district head feels that he only gets the delegation of functions that must be carried out within his authority's limits as regulated in the existing provisions. Suitable tasks about fulfilling community rights to permit documents (IMB), which become legal evidence of asset ownership, require many resources and funds. On a tremendous interest in fulfilling the community's rights as citizens, besides not being included in the provisions for delegation of regulated affairs; This is not the case for the Head of District in making decisions. 


\subsection{Measuring Devolution and Transformation of Potential Improvement of Public Service Quality}

Before explaining devolution, in line with the transfer of part of the Regent's authority to the sub-district head, the types of decentralization are first put forward to make the concepts of decentralization and devolution clearer in photographing the phenomenon of decentralization at the local level. Decentralization can be defined as the transfer of responsibility for planning, management, and management of resources and allocation of funds from the central government and its institutions to (a) a field unit of central government ministries, (b) units under the central government or levels of government, (c) semi-autonomous public authorities or companies, (d) regional, regional or functional authorities, or (e) private or non-governmental organizations (NGOs) [12]. Borrowing from the definition of decentralization, in this research, what is meant by decentralization is the transfer of part of the Regent's responsibility or authority to regional / sub-district officials.

Four forms of decentralization can be distinguished by the level of authority and power or their functions' scope. The first form is deconcentration, which is the devolution of responsibility from the central government to the regions. Deconcentration involves the transfer of functions in the central government's hierarchy through shifting workloads from central departments to field officers or shifting responsibilities to local administrative units that are part of the central government structure [11]. It can operate at different scales and to different degrees. For example, deconcentration may not increase local input (aspirations) in decision making because it only allows administrative processes to be carried out at the local level [13]. Decentralization in deconcentration is often referred to as administrative decentralization, aiming to implement delegated tasks more effectively and efficiently.

The second form of decentralization is delegation (delegation), concerning delegation to semi-autonomous organizations. Delegations concerning the delegation of authority to regional or functional institutions, parastatal organizations (for example, banks, airlines, railways, television stations, and telephone services), or particular project implementing units that often operate independently of central government regulations regarding personnel recruitment, contracts, budgeting, procurement, and other matters, as well as acting as agents for the state in carrying out designated functions with the primary responsibility remaining to the central government[11]. In short, this form represents delegation of decision-making and management authority for specific functions for organizations that are not under the direct control of the central government. This authority organization can be delegated to a public company or a specific project implementing unit.

Third, devolution involves the transfer of function or decision-making authority to regional governments legally incorporated, such as a state, province, district, or city [11]. Devolution is the creation or financial or legal strengthening of local governments, which are substantial outside the central government's direct control.

In devolution, local government units are autonomous and independent, and their legal status makes local governments separate or distinct from the central government. Typically, local governments have clearly defined and legally recognized geographic boundaries under which they exercise exclusive powers to perform the functions assigned or provided explicitly. Local governments have management authority or legislation to increase revenues and make local expenditures [12].

The fourth is transfer to non-government institutions or privatization, a shift in responsibility for activities from the public sector to private or quasi-public organizations that 
are not part of the government structure [11]. Organizations are given responsibility, license, regulate, or supervise society members, where previously these functions were performed or regulated by the government. In some cases, the government can decentralize by shifting responsibility for providing services previously carried out by the state or public companies to be owned or controlled by private companies. Governments can also transfer responsibilities to organizations representing various interests in society and those founded and operated by members of their organizations. For example, farmer cooperatives, credit associations, village development organizations, labor unions, or women's organizations and youth organizations [12].

The four types of decentralization above will conceptually be used to analyze the Regent's authority's decentralization to the Head of District. Researchers in the study assumes that decentralization in devolution will improve public service quality in the sub-districts. This assumption is built based on the data collected and the basis for the researchers' assessment of the importance of the concept of devolution itself.

In the previous section regarding the Regent's policy regulating the issue of delegation of authority, the delegation of part of the Regent's authority to the Head of District covers 13 government affairs. The delegation of part of the Regent's authority to the sub-district head is the delegation of duties and includes the support of personnel, equipment/equipment, funding, and documentation. This shows that the decentralization of some of the district heads' powers is administrative decentralization. It is not logical; when there is a transfer of rights, obligations, and responsibilities of a part of government affairs to a unit/work unit in the region, resources do not accompany it. For the implementation of general work tasks, support is needed, not only an authority stated on a sheet of paper. However, adequate resources are also needed both in quantity and quality.

In carrying out the delegation task, the Head of Sub-District must be guided by the technical guidelines for implementing the delegated government affairs. The Head of the District was not given the power to make decisions outside of the technical provisions in providing services. In the case of IMB licensing services, the Head of the sub-district should do from the application for an IMB permit submitted by the applicant is clear, namely examining the application until the signing of the license. Apart from the existing provisions, what is incredibly strategic regarding the community's rights as citizens regarding the ownership of the IMB is not under his authority to think about, let alone have to decide.

When in the service process (including IMB), there is a problem or problem-related to the implementation of the delegated tasks, the Head of District is obliged to carry out technical functional and operational technical coordination with the relevant regional apparatus. Thus, it is clear that the Head of the district's space is very small or impossible to decide how the best service is carried out and how the community's rights as citizens are given.

IMB licensing services are one of the services that exist in the sub-district, which bring income to the region from the fees collected by the sub-district. As a result, the delegation of part of the authority from the Regent to the Head of District. The levies collected by the provisions must be deposited to the Regional Treasury as regional revenues, and the results reported to the Regent through the relevant Regional Apparatus. As a consequence of the retribution for the IMB service, service providers, in this case, the sub-district head, was asked to set revenue targets. For this, the Head of District aims to receive this service retribution based on previous years' experience. The target is neither too high nor too low. If it is too high and then it is not achieved, it affects performance, but it indicates achievement if the target is too high. 
The target made is at least to spur the Head of District, at least to achieve it. For this, the sub-district party did what was not regulated in the provisions but was included in the planned activities, namely socialization. This socialization is not a strategic matter because it is a routine activity scheduled in the activity planning every year. This socialization is intended for people who want to build houses to be taken care of and equipped with an IMB. Based on this provision, it is clear that the Regent's decentralization to the Head of District constitutes administrative decentralization. In this form of decentralization, the governmental affairs delegated will continue to run as they should and be natural. This means that services do not have a significant impact on society as citizens. Because it is impossible for the Head of District to make decisions outside of the existing provisions even as a public service provider, the Head of District has the desire to do his best for the community's benefit. However, with a decentralized model in the sense of devolution, the Head of District will provide public services to the community in his position as citizens. In other words, decision-making in the administration of public services delegated by the Regent is also given or becomes autonomy from the Head of District, even though the sub-district is not an autonomous region. The decentralization picture from the Regent to the Camat is like decentralization from the center to the Regency / City Government. So this devolution can also happen to the local government from the Regent to the Head of District.

Furthermore, the decentralization of the Regent to the Head of District was also accompanied by budget support. This budget support is minimal compared to service duties' scope, which is its duties and responsibilities. How can the Head of District allocate expenditures in the sub-district on all excellent quality public services? Of course, it is implausible. In this condition, for the IMB licensing service alone, the sub-district head should have made a more rational target. With devolution, it is hoped that the Head of Sub-District can explore the potentials in his area, which can later be used to increase financial support in the delivery of public services. In this context, decentralization and the form of devolution are oriented towards the implementation of government affairs delegated by the Regent (empowerment, population services, housing, and settlement area arrangements, etc.) so that they can be closer, faster, and more precise in providing services according to the needs of the community.

\section{Conclusion}

The conclusions that can be drawn from the results of this research are as follows:

The decentralization of part of the Regent authority to the Head of District is a form of administrative decentralization. Based on the above analysis, decentralization in the form of devolution that can be given to the sub-district level government has implications for changes in three ways:

a. Changes in service decision making that have been decided by the Regent or the bureaucracy at the regency level shift to the sub-district level.

b. Changes in accountability as a consequence of shifting decision making, which has become the

Authority of the Head of District can be more accountable.

c. Changes in the financing budgeting for the consequences of decentralization from the Regent to the Head of District may come from the manageable potential at the subdistrict level. 


\section{References}

[1] H. Alderman, "Do local officials know something we dIno not? Decentralization of targeted transfers in," J. Public Econ, vol. 83, pp. 375-404, 2002.

[2] K. P. Andersson, C. C. Gibson, and F. Lehoucq, : "The politics of decentralized natural resource governance," Political Sci. Politics, vol. 37, pp. 421-426, 2004.

[3] C. W. Andrews and M. S. Vries, "High expectations, varying outcomes: decentralization and participation in Brazil, Japan, Russia, and Sweden," Int. Rev. Adm. Sci, vol. 73, pp. 424-451, 2007.

[4] N. Awortwi, : "An unbreakable path? A comparative study of decentralization and local government development trajectories in Ghana and Uganda," Int. Rev. Adm. Sci, vol. 77, pp. 347-377, 2011.

[5] G. S. Cheema and D. A. Rondinelli, Decentralization and development: Policy implementation in developing countries. Sage Publications, 1983.

[6] U. Karumba, : "Local government-citizen participation and rural development: reflections on Uganda's decentralization system," Int. Rev. Adm. Sci, vol. 77, pp. 171$186,2010$.

[7] P. Mawhood, Local Government in the Third World. Chichester, UK: John Wisley and Sons, 1983.

[8] M. B. Miles and A. M. Huberman, Qualitative data analysis: Sourcebook of new methods. Thousand Oaks, CA: SAGE Publications, 1984.

[9] W. O. Patrick and F. Scott, : "Decentralization in Developing Countries," Encyclopedia of Public Administration and Public Policy, vol. 2nd and, pp. 498-503, 2011.

[10] D. A. Rondinelli, "Government decentralization in comparative perspective: theory and practice in developing countries," Int. Rev. Adm. Sci, vol. 47, pp. 133-145, 1980.

[11] D. A. Rondinelli, "Implementing decentralization programmes in Asia: A comparative analysis," Public Adm. Dev., vol. 3, no. 3, pp. 181-207, 1983.

[12] D. A. Rondinelli, J. R. Nellis, and G. S. Cheema, Decentralization in Developing Countries: A Review of Recent Experience. Washington: The World Bank, 1983.

[13] R. Unkempt Seymour and S. Turner, "Otonomi Daerah: Indonesia's Decentralisation Experiment,” New Zealand Journal of Asian Studies, vol. 4,2, pp. 33-51, 2002. 